\title{
Effects of turf algae on recruitment and juvenile survival of gorgonian corals
}

\author{
Cristina Linares $^{1, *}$, Emma Cebrian $^{2}$, Rafel Coma ${ }^{3}$ \\ ${ }^{1}$ Departament d'Ecologia, Universitat de Barcelona, Diagonal 645, 08028 Barcelona, Spain \\ ${ }^{2}$ Departament de Ciències Ambientals, Facultat de Ciències, Universitat de Girona, Campus Montilivi, \\ 17071 Girona, Spain \\ ${ }^{3}$ Centre d'Estudis Avançats de Blanes-CSIC, Accés Cala Sant Francesc 14, 17300 Blanes, Girona, Spain
}

\begin{abstract}
During the last 2 decades, the widespread temperate gorgonian Eunicella singularis has been among the species most affected by climate-induced mortalities. Recruitment and juvenile survival play crucial roles in the recovery process of this species, but turf algae may affect these early life history processes. We investigated the effects of turf algae on recruitment and juvenile survival of E. singularis using in situ turf-removal and turf-exposure experiments. The experiments were performed at a depth of 15 to $20 \mathrm{~m}$ off the island of Menorca (Balearic Islands, NW Mediterranean Sea) between April 2008 and July 2009. The turf-removal experiment indicated that exposure to turf algae caused up to a 5-fold reduction in the recruitment of the gorgonian species. The turf-exposure experiment revealed that transplanted juveniles exposed to turf algae overgrowth lost biomass and exhibited a threefold increase in juvenile mortality. These results demonstrate the negative effects that turf algae can exert on early stages of gorgonian species; in turn, this may affect their recovery capacity and population dynamics. Given that most Mediterranean invasive algae form a persistent turf, an increase in turf algae abundance may exacerbate these negative effects.
\end{abstract}

KEY WORDS: Turf algae $\cdot$ Gorgonian coral $\cdot$ Early life history stages $\cdot$ Recruitment $\cdot$ Survival Mediterranean Sea

Resale or republication not permitted without written consent of the publisher

\section{INTRODUCTION}

Marine ecosystems are in serious decline because of overfishing, pollution, habitat destruction, invasive species and climate change (Jackson et al. 2001, Hughes et al. 2003, Halpern et al. 2008). Consequently, a major goal of ecologists has been predicting how these ecosystems will respond to local and global environmental changes. The Mediterranean Sea offers a unique opportunity to address the complexities of cumulative impacts because the rich biodiversity of the region has been affected by multiple stressors, and has changed more rapidly than many other world regions (Coll et al. 2010, Costello et al. 2010, Coma et al. 2011, Calvo et al. in press).

Recruitment is crucial for the persistence and resilience of marine benthic communities, and it is regulated by several early life history processes, including larval supply, settlement and post-settlement survival (Caley et al. 1996, Gosselin \& Qian 1997, Hughes et al. 2000). Disturbances that disrupt these early stage processes can result in compromised or failed recruitment, which can profoundly affect future population dynamics (Gaines \& Roughgarden 1985). Therefore, it is crucial to investigate the potential impacts of disturbances on the early life history stages of organisms. 
Turf algae are dense, multispecies assemblages of filamentous benthic algae that are commonly found on many tropical and temperate intertidal and subtidal shores (Hay 1981, Steneck \& Dethier 1994). In recent decades, evidence has emerged of a trend of turf algae increases in relation to enhanced levels of disturbance (e.g. sediment loads and nutrients) in temperate and tropical coastal ecosystems (Airoldi et al. 1995, Airoldi 1998, Vermeij 2006, Vermeij et al. 2010). Furthermore, in the Mediterranean Sea, some of the most invasive species consist of turf-forming macroalgae that are triggering substantial changes in the structure of benthic algal communities (Piazzi et al. 2001, Streftaris \& Zenetos 2006). Turf algae have been shown to affect tropical coral recruitment negatively, either through preemption of settlement surfaces or by increasing the risks of post-settlement mortality (Edmunds \& Carpenter 2001, Birrell et al. 2005, Vermeij 2006, Arnold et al. 2010, Vermeij et al. 2010). Therefore, we hypothesised that turf algae abundance would have negative effects on the recruitment of temperate sessile invertebrate species.

Gorgonians are emblematic species of sublittoral communities because they are one of the main contributors to the 3-dimensional structure of the community, comprise a major part of its diversity, and play an important role in plankton-benthos coupling (Gili \& Coma 1998). However, gorgonians are among the most affected benthic species from escalating climate-related threats that affect the Mediterranean Sea (Coma et al. 2009, Garrabou et al. 2009, Linares \& Doak 2010). Although certain gorgonian species exhibit low recruitment rates (Garrabou \& Harmelin 2002, Coma et al. 2004, Linares et al. 2007), Eunicella singularis displays a size distribution that is dominated by early life history stages, suggesting that the species is not limited by recruitment (Linares et al. 2008a, Gori et al. 2011). However, mass mortality events have lead to the loss of approximately half of the gorgonian population (Coma et al. 2006). In the face of such large disturbances, larval recruitment is a critical step in the recovery process of gorgonian forests. Brooding and surface brooding are the dominant modes of development in Mediterranean gorgonians (Vighi 1970, Coma et al. 1995a,b, Ribes et al. 2007, Linares et al. 2008b) and contribute to the short-distance dispersal of the species that have been examined to date (Ledoux et al. 2010, Mokhtar-Jamaï et al. 2011)

The aim of our work was to use field experiments to investigate the effects of turf algae on the recruitment and survival of juvenile colonies of the Mediterranean gorgonian Eunicella singularis.

\section{MATERIALS AND METHODS}

\section{Study site}

The present study was performed at 3 locations on the north coast of Menorca within the 'Nord de Menorca' Marine Protected Area (Balearic Islands, Spain, NW Mediterranean; Fig. 1). The study area remains largely unaffected by anthropogenic impacts because there are no sources of pollution (e.g. eutrophication, heavy metals, HAPs; Sales \& Ballesteros 2009, Sales et al. 2011). In addition, fishing has been prohibited since 2000. Eunicella singularis is an abundant species on the north-sloping underwater cliffs of the island, where it dwells in rocky bottom habitats in exposed areas either on walls or on large blocks from depths of 15 to $40 \mathrm{~m}$ (Coma et al. 2006).

In 1999, a regional mass mortality event severely affected this species at the study area, causing the

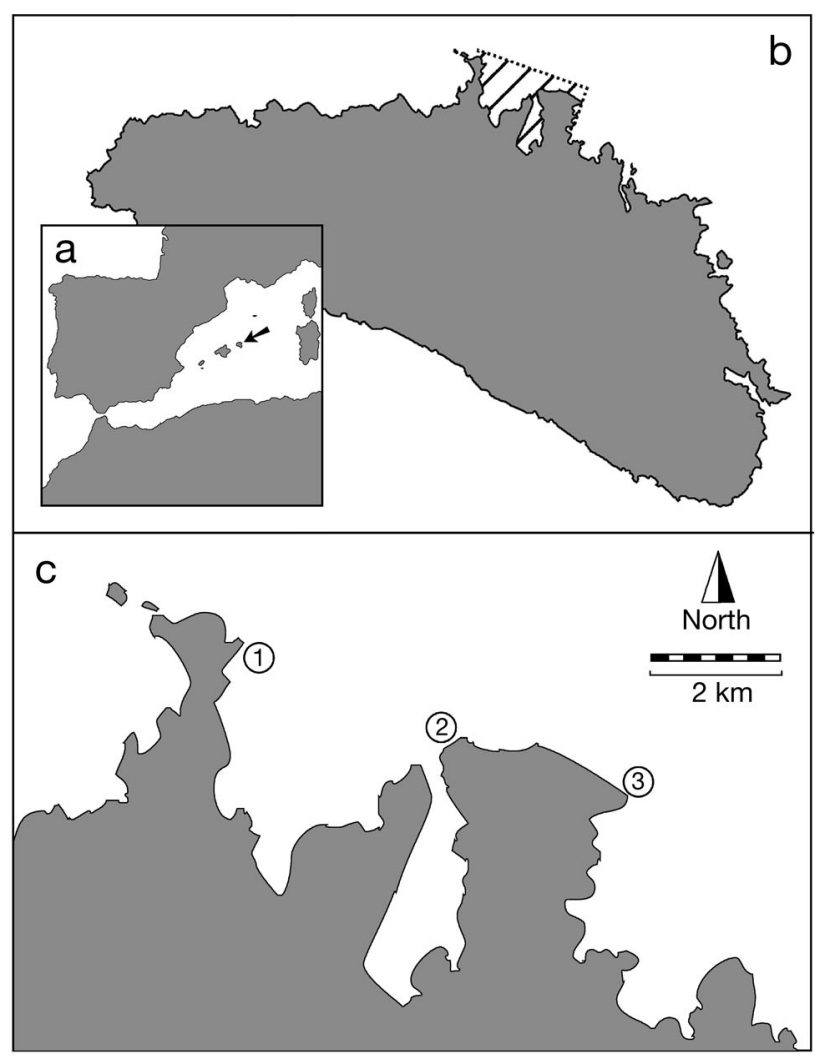

Fig. 1. Study locations. (a) Menorca (arrow) in the Balearic Islands, NW Mediterranean. (b) Study area on the north coast of Menorca (hatched area). (c) Study sites: the turfremoval experiment was performed at Cap Roig (1; $\left.40^{\circ} 5.9^{\prime} \mathrm{N}, 4^{\circ} 5.57^{\prime} \mathrm{E}\right)$ and Na Ponsa $\left(2 ; 40^{\circ} 4.3^{\prime} \mathrm{N}, 4^{\circ} 8.16^{\prime} \mathrm{E}\right)$; the turf-exposure manipulative experiment was carried out at the Cova de Ses Bruixes $\left(3 ; 40^{\circ} 3.4^{\prime} \mathrm{N}, 4^{\circ} 10.14^{\prime} \mathrm{E}\right)$ 
loss of $\sim 46 \%$ of the population (Coma et al. 2006). In addition, the Balearic Islands are one of the regions most affected by invasive algae within the Mediterranean Basin (Zenetos et al. 2010). Caulerpa racemosa v. cylindracea, Asparagopsis taxiformis, Womersleyella setacea and Acrothamion preissi are present in the littoral of Menorca Island, and populations of $W$. setacea and $A$. preissi in particular have been observed to develop dense and thick turfs in some habitats (Ballesteros 2004). These turf algae have been documented as threats to sublittoral habitats in various areas of Menorca and on other Balearic islands (Ballesteros 2004). Our assessment of algal biomass and species abundance at both study locations revealed that Haliptilon virgatum (Zanardini) Garbary \& Johansen, Peyssonnelia squamaria (Gmelin) Decaisne \& Sphacellaria cirrosa (Roth) C. Agardh were the dominant native algal species of the turf community, which reached a biomass of $\sim 300 \mathrm{~g} \mathrm{DW} \mathrm{m}^{-2}$. The turf community was observed to consist of up to $30 \%$ invasive algae ( $W$. setacea and A. preissi, $\sim 60 \mathrm{~g} \mathrm{DW}^{-2}$ ). Within this community, we conducted a turf-removal experiment and a turf-exposure experiment to examine the effects of turf algae on the early life history stages of E. singularis.

\section{Recruitment}

We conducted a turf-removal experiment in situ to assess the effects of turf algae on the recruitment of Eunicella singularis. In the early spring of 2008 (before larval spawning; Ribes et al. 2007), we randomly marked 40 quadrats of $40 \times 40 \mathrm{~cm}$ with plastic screws placed at a depth between 15 and $20 \mathrm{~m}$ in each of 2 localities (Cap Roig and Na Ponsa, Fig. 1). We chose a random distance from a spot within the community as a randomisation procedure to determine the place to locate each quadrat. Digital stopwatches were used to produce the random numbers (using numbers at the level of 1/100ths). Divers began at a spot within the community. The divers first chose a random direction (north, south, east or west, according to the numbers 1 to 4 ) and subsequently chose a random distance (numbers 0 to 9). A $50 \mathrm{~cm}$ ruler was used as the unit of distance (i.e. number 5 means $5 \times$ $50 \mathrm{~cm}$ or $2.5 \mathrm{~m}$ from the initial spot). The 4 corners of each quadrat were marked with plastic screws, one of which was labelled for future identification. The total algal cover was scraped using a paint scraper until clean bare rock was exposed from 20 of the quadrats (the 'Turf-removal' experimental treat- ment). The algal cover was maintained at the other 20 quadrats (the 'Non-removal' control treatment). All of the colonies present in each quadrat were individually identified and mapped. At the end of July 2008, we counted in situ the number of new recruits ( 3-5 mm height) in each quadrat with the aid of a hand lens.

\section{Survival and fitness}

Although desirable, long-term experimental plots to compare recruit survival in plots with and without turf algae were not used for several reasons. First, the rapid dynamics of turf algae (Airoldi 2000) make the maintenance of such experiments logistically difficult. Second, the periodic eradication of turf may affect the survival of gorgonian recruits. Third, periodic turf eradication favours the development and growth of invasive turf species (Klein \& Verlaque 2011). Therefore, between July 2008 and June 2009, we estimated in situ the survival of post-recruitment Eunicella singularis colonies within 40 plots selected in both of the study locations (Cap Roig and Na Ponsa, Fig. 1), all of which were exposed to the natural overgrowth of the turf algae present at the study area.

We conducted a turf-exposure manipulative experiment to examine the effects of overgrowth of turf algae on juvenile colonies of Eunicella singularis. Small apical tips $(<5 \mathrm{~cm})$, each of which was obtained from a different colony, were placed in 2 different environments: 'non-overgrowth' (i.e. not exposed to contact with turf algae; experimental treatment) and 'turf-overgrowth' (i.e. exposed to overgrowth by turf algae; control treatment). The apical colony tips of 80 healthy E. singularis were haphazardly sampled at Cova de Ses Bruixes between 15 and $20 \mathrm{~m}$ of depth (Fig. 1). Each colony's apical tip (hereafter known as colony) was attached to the experimental plates (Fig. 2). These plates were built from 3 PVC disks (each $10 \mathrm{~cm}$ in diameter). Two rubber layers were used to separate the PVC plates. Each PVC disk had 8 holes ( $1 \mathrm{~cm}$ in diameter) for the colonies. The entire set was held together with screws. The colonies were attached to the experimental plates without putty but were held mechanically simply by perpendicular cuts that had been previously made in the rubber layers (one cut per layer). Each experimental plate had labels to distinguish the experimental treatments and colonies within the plate. Forty colonies were placed in 5 experimental plates (8 per plate), and 40 colonies were placed in 5 control plates. The sampled colonies were randomly attached to the plates under- 


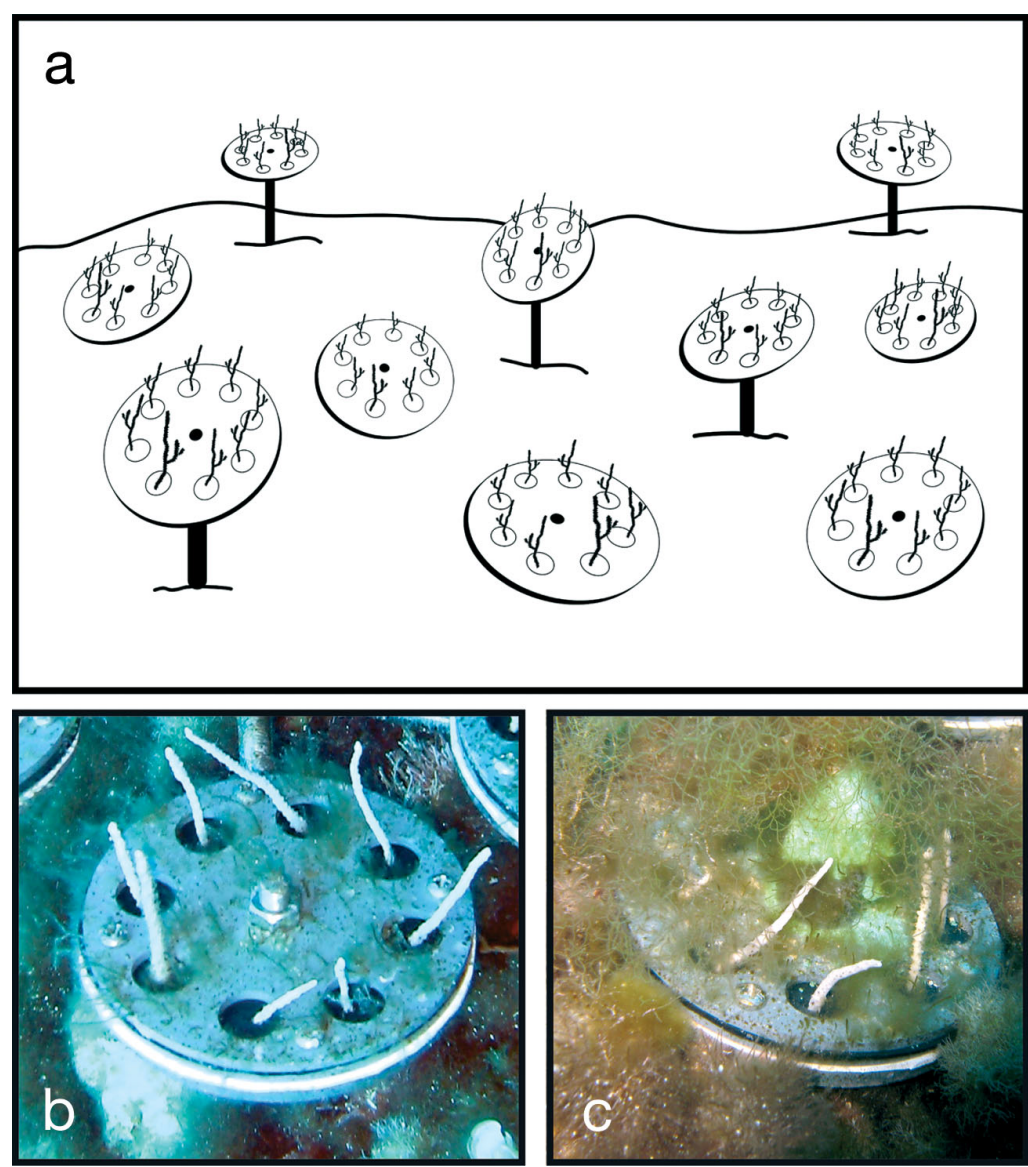

Fig. 2. Eunicella singularis. (a) Experimental design for studying the effects of turf algae on the survival of juvenile colonies (control plates attached to vertical supports). Detail of colonies (b) not exposed (control) and (c) exposed to overgrowth by turf algae. Both pictures were taken one month after the beginning of the experiment

data, we did not take into account the detachment of a transplanted colony from the experimental plate $(\sim 10 \%$ on both treatments and occurring shortly after the beginning of the experiment) because we considered these events to indicate methodology failures in contrast to the mortality caused by turf algae that resulted in the loss of the living tissue of the colony.

The mean diameter of the colonies was used as an indicator of gorgonian fitness based on the relationship between biomass and diameter. Biomass has been shown to be a good indicator of gorgonian fitness because biomass falling below a critical threshold indicates the first appearance of partial mortality (Coma et al. 2009). At the end of the experiment, 10 apical tips from the experimental plates (which were not exposed to algal turf) and 10 from the control plates (which were exposed to algal turf) were collected. Their diameters were measured in the laboratory using a micrometer under a stereomicroscope. It should be noted that although we installed 40 apical tips at each treatment, the low number of colonies that was used was due to the low survivorship obtained from the control plates.

\section{Statistical analyses}

water by divers less than an hour after collection. The 5 control plates were kept on a support slightly above the rocky substrate ('non-overgrowth') at the minimum distance needed to prevent overgrowth by turf algae and limit the exposure to variation in environmental conditions to those occurring on the substrate (previous preliminary experiments had been conducted to determine this distance). The other 5 plates were installed such that they would be completely attached to the rocky substrate leading to the turf algae overgrowth ('turf-overgrowth', Fig. 2).

Special care was taken to distribute all of the plates randomly within the same area (separated $<1 \mathrm{~m}$ ) and at the same depth to expose all of the colonies to similar environmental conditions. The experiment lasted from April 2008 to July 2009. At the end of the experiment, we calculated the survival rate and the mean diameter of the colonies that survived on each of the 5 experimental and 5 control plates. To analyse the
The effects of treatment and location on gorgonian recruitment were assessed using a 2-way ANOVA. Alternatively, a $t$-test was used to examine the differences in survival and diameter between the experimental and control colonies at the end of the turf-exposure manipulative experiment. The values of survival from the turf-overgrowth treatment found in the manipulative experiment were also compared with the in situ survival of small colonies obtained by monitoring the installed plots using a $t$ test. For all of the variables, the homogeneity of variances was verified by Cochran's $C$-test, and the normality was assessed by the Kolmogorov-Smirnov test prior to the analysis. If the data did not follow a normal distribution, the Wilcoxon rank sum test was used. All of the statistical analyses were performed in Statistica 8.0. 


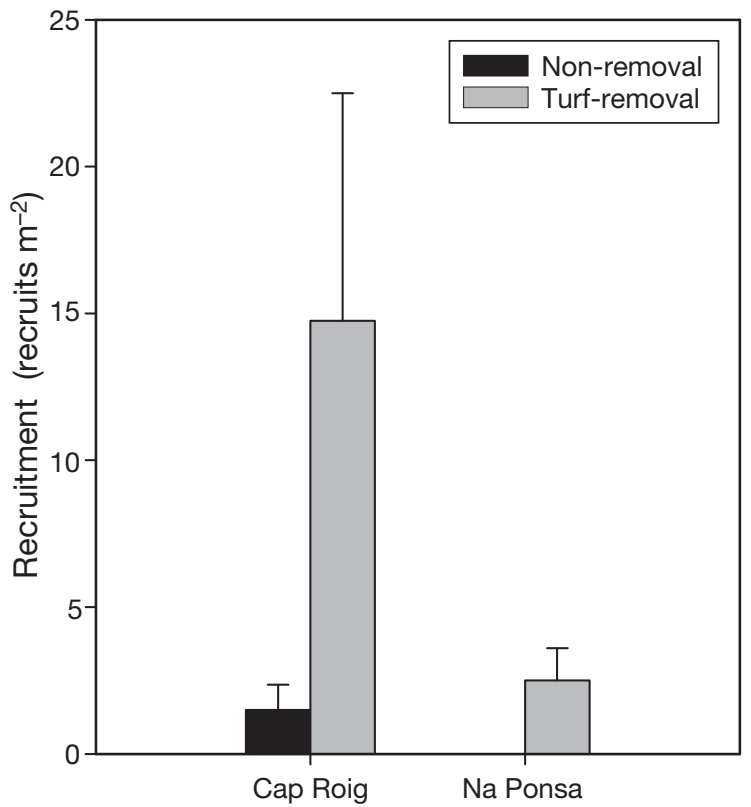

Fig. 3. Eunicella singularis. Recruitment (number of recruits per $\mathrm{m}^{2}$; mean $\pm \mathrm{SD}$ ) observed under the 'Turf-removal' treatment (experimental) conditions and under the 'Nonremoval' treatment (control) conditions at the 2 study locations: Na Ponsa and Cap Roig

\section{RESULTS}

\section{Recruitment}

At both study locations, recruitment was significantly higher on those quadrats exposed to the 'Turfremoval' treatment (experimental) than on those exposed to the 'Non-removal' treatment (control; 2way ANOVA, $\mathrm{p}<0.01$ ). Turf algae removal increased recruitment approximately 5-fold at the Cap Roig location. The recruitment rates at Cap Roig were also 4-fold higher than those obtained at Na Ponsa (site; 2-way ANOVA, p < 0.05). Within the 'Turf-removal' quadrats, the mean number of recruits recorded in Cap Roig and Na Ponsa were $14.7 \pm 15.5( \pm \mathrm{SD})$ recruits $\mathrm{m}^{-2}$ and $2.7 \pm 2.2( \pm \mathrm{SD})$ recruits $\mathrm{m}^{-2}$, respectively (Fig. 3). Notably, no recruitment was recorded in the Na Ponsa location control quadrats (Fig. 3).

\section{Survival and fitness}

Three months after the beginning of the experiment, the control plates were overgrown by turf algae in a manner similar to that observed in the nearby benthic community, whereas the experimental plates were not overgrown. Periodic inspections indicated that the turf algae did not overgrow the
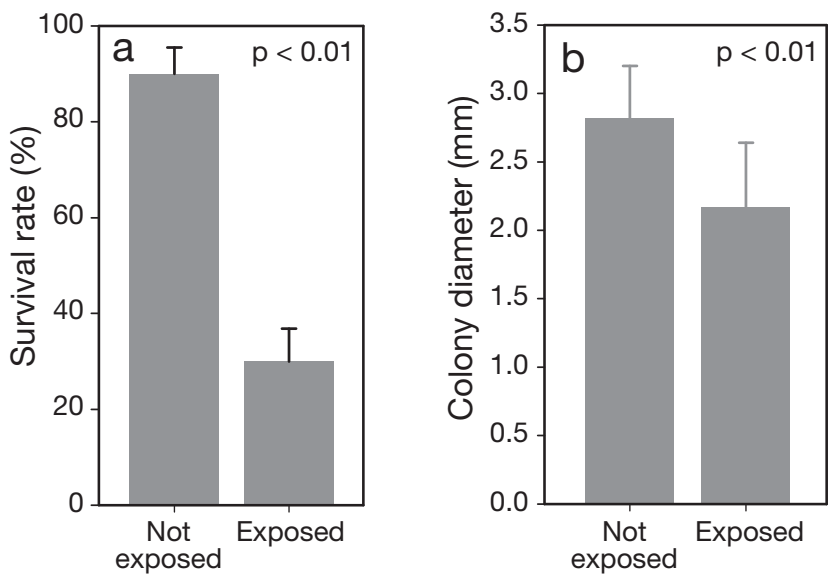

Fig. 4. Eunicella singularis. Turf-exposure manipulative experiment. Contrast of (a) survival rate (mean \pm SD) and (b) colony diameter (mean $\pm \mathrm{SD}$ ) between transplanted colonies exposed and unexposed to turf algae overgrowth

experimental plates throughout the manipulative experiment. At the end of the manipulative experiment, $90 \pm 6 \%$ (mean $\pm \mathrm{SD}$ ) of the transplanted colonies survived under the non-overgrowth conditions. In contrast, the survival of transplants exposed to the overgrowth of turf algae was $30 \pm 7 \%$ (mean $\pm \mathrm{SD}$ ). Thus, the manipulative experiment demonstrated that the survival rate of juvenile colonies exposed to overgrowth by turf algae was 3 -fold lower than that of unexposed colonies ( $t$-test, $p<0.01$; Fig. $4 a)$. The manipulative experiment also indicated that Eunicella singularis colonies exposed to turf algae overgrowth displayed a diameter that was $23 \%$ smaller $(2.1 \pm 0.4 \mathrm{~mm}$, mean $\pm \mathrm{SD})$ than that of unexposed colonies $(2.8 \pm 0.4 \mathrm{~mm}$, mean $\pm \mathrm{SD})(t$-test, $\mathrm{p}<0.01$; Fig. 4b).

The survival rate of small colonies on the 40 nonmanipulated plots (i.e. those exposed to turf algae) between July 2008 and June 2009 did not vary between locations $(39 \pm 38 \%$ in Cap Roig vs. $12 \pm$ $25 \%$ in Na Ponsa; $t$-test, $\mathrm{p}=0.25$ ) and exhibited a mean value of $26 \pm 18 \%$ (mean $\pm \mathrm{SD}$ ). The survival rate of colonies in these non-manipulated plots did not differ from that observed of the colonies exposed to overgrowth by turf algae in the turf-exposure manipulative experiment $(t$-test, $p=0.88)$.

\section{DISCUSSION}

This study offers the first quantitative data on the effects of turf algae on the process of recruitment of a Mediterranean marine invertebrate, specifically, the widespread gorgonian Eunicella singularis. Our 
results demonstrate that turf algae have the capacity to affect gorgonian population dynamics by reducing recruitment and juvenile survival, as well as by inhibiting gorgonian growth.

Differences in recruitment between the study locations are probably related to the spatial variability in the recruitment of gorgonian species (Gotelli 1988). However, the turf-removal experiment produced a marked increase in recruitment, indicating that the presence of turf algae sharply reduced the recruitment of Eunicella singularis. The effects of turf algae on the gorgonian recruitment appear to depend on a decrease in larval access to suitable substrata for settlement and on the effect of physical stress of algal overgrowth on the colonies, as has been observed in coral reefs (Arnold et al. 2010).

The turf-exposure experiment demonstrated that the survival of juvenile gorgonians exposed to the turf algae was 3-fold lower than that of the unexposed juveniles (30\% vs. $90 \%$, respectively). The survival rate of juvenile colonies exposed to turf algae in the turf-exposure experiment did not differ from that exhibited by the small colonies in the nonmanipulated plots $(\sim 25 \%)$. The reduction in biomass of the juvenile colonies exposed to turf algae from the turf-exposure experiment suggests that turf algae might reduce juvenile colony survival through the physical stress that algal overgrowth exerts on the gorgonian, which affects its feeding capacity and leads to a loss of biomass. These effects jeopardise the viability of the gorgonian because tissue mortality has been observed to begin after a threshold of biomass loss has been reached (Coma et al. 2009).

The negative effects of turf algae on the examined gorgonian species are similar to those documented for other coral species (Birrell et al. 2005, Vermeij \& Sandin 2008, Arnold et al. 2010). However, as highlighted in other studies, other mechanisms could be involved in the observed negative effects caused by the turf algae beyond the physical effects of overgrowth and space occupation on the recruitment and survival of gorgonians, such as allelopathic interactions of macroalgae and cyanobacteria with corals (Kuffner et al. 2006), or the effects of algae-associated pathogens (Nugues et al. 2004).

The lack of data on the recruitment and survival rates of Eunicella singularis in areas without turf algae prevented us from contrasting the results obtained in the present study with those obtained from other locations and areas. However, in contrast to other Mediterranean gorgonians, which typically exhibit low recruitment rates (Garrabou \& Harmelin 2002, Coma et al. 2004, Linares et al. 2007), the size- frequency distribution of various E. singularis populations obtained in previous studies indicates a high recruitment rate and a high post-settlement survival of the species (Linares et al. 2008a, Gori et al. 2011). Consequently, the present study shows that an increased abundance of turf algae may negatively affect gorgonian population dynamics by reducing recruitment and juvenile survival. These effects would slow down the recovery capacity of the populations and reduce the long-term resilience of gorgonian forests, especially those exposed to recurrent disturbances.

The negative effects on the early life stages of Eunicella singularis were found in the presence of a biomass of turf algae that reached a value of approximately $300 \mathrm{~g} \mathrm{DW} \mathrm{m}^{-2}$, from which the invasive algae Womersleyella setacea and Acrothamion preissii accounted for $\sim 30 \%$ of the biomass. This biomass of turf algae was high compared to those observed in other Mediterranean locations (i.e. 90-150 g DW m ${ }^{-2}$ at Calafuria, Airoldi 2000), but similar values are commonly observed in areas that have been densely occupied by invasive turf species (i.e. $500 \mathrm{~g} \mathrm{DW} \mathrm{m}^{-2}$, Cabrera National Park, Balearic Islands, Cebrian \& Ballesteros 2009, 2010).

Native Mediterranean turf algae exhibit a seasonal reduction of turf cover and biomass during the winter months (Airoldi 2000). In contrast, this pattern does not occur in invasive species, such as Womersleyella setacea (Rodriguez-Prieto et al. 2010), which persist throughout the year. In some Mediterranean localities, various turf-forming invasive species can constitute up to $80 \%$ of the algal biomass (e.g. Scandola Nature Reserve, Corsica; authors unpubl. data). The replacement of perennial canopy-forming algae by opportunistic taxa, such as turf-forming algae, affects not only temperate areas, such as the Mediterranean, but is also a source of concern in tropical ecosystems (Krause-Jensen et al. 2008, Vermeij et al. 2010). Enhanced loads of sediment in coastal habitats and water eutrophication have been identified as the main drivers of the shift from the dominance of canopy-forming species to algal turfs (Airoldi et al. 1995, Benedetti-Cecchi et al. 2001, Gorgula \& Connell 2004). Although the effects of algal turfs on macrophyte assemblages have been explored in temperate systems (Kennelly 1987, Airoldi 1998, Gorman \& Connell 2009), the outcome of the interactions between turf algae and marine invertebrates remains largely unknown. An increase in turf algae abundance (Airoldi et al. 1995, Airoldi 1998, Vermeij et al. 2010), in combination with the fact that some of the most invasive Mediterranean algae form a thick and 
persistent turf over the substratum, might indicate an increase of the potential negative effects of turf algae on the population dynamics and recovery capacity of Eunicella singularis and, probably, of other benthic invertebrates.

Acknowledgments. The authors thank Dr. E. Ballesteros for his help in algal identification. We also thank Dr. J. Garrabou and C. Marschal for providing the PVC disks for gorgonian transplants. We are grateful to the entire staff of the 'Reserva Marina del Nord de Menorca' and 'Direcció General de Pesca del Govern de les Illes Balears' for providing logistic support. Financial support was provided by the 'Consell Insular de Menorca' and the 'Ministerio de Ciencia e Innovació (MCI)' projects CGL2010-18466 and CTM2009-08045. C.L. and E.C. were funded by a Juan de la Cierva Postdoctoral Fellowship from the MCI and are part of the Marine Conservation research group (2009SGR174); R.C. is a member of the Marine Biogeochemistry and Global Change research group (2009SGR142) from the Generalitat Catalunya.

\section{LITERATURE CITED}

Airoldi L (1998) Roles of disturbance, sediment stress, and substratum retention on spatial dominance in algal turf. Ecology 79:2759-2770

Airoldi L (2000) Effects of disturbance, life-histories and overgrowth on coexistence of algal crusts and turf. Ecology 81:798-814

Airoldi L, Rindi F, Cinelli F (1995) Structure, seasonal dynamics and reproductive phenology of a filamentous turf assemblage on a sediment influenced, rocky subtidal shore. Bot Mar 38:227-237

Arnold SN, Steneck RS, Mumby PJ (2010) Running the gauntlet: inhibitory effects of algal turfs on the processes of coral recruitment. Mar Ecol Prog Ser 414:91-105

Ballesteros E (2004) Espècies marines invasores: un problema ambiental emergent a les illes Balears. In: Pons GX (ed) IV Jornades de medi Ambient de les Illes Balears. Ponències i resums, 13-15. Soc Hist Nat Balears, Palma de Mallorca

> Benedetti-Cecchi L, Pannacciulli F, Bulleri F, Moschella PS, Airoldi L, Relini G, Cinelli F (2001) Predicting the consequences of anthropogenic disturbance: large-scale effects of loss of canopy algae on rocky shores. Mar Ecol Prog Ser 214:137-150

Birrell CL, McCook LJ, Willis BL (2005) Effects of algal turfs and sediment on coral settlement. Mar Pollut Bull 51: 408-414

Caley MJ, Carr MH, Hixon MA, Hughes TP, Jones GP, Menge BA (1996) Recruitment and the local dynamics of open marine populations. Annu Rev Ecol Syst 27: $477-500$

Calvo E, Simó R, Coma R, Ribes M and others (2011) Impact of climate change on Mediterranean marine ecosystems: the case of the Catalan Sea. Clim Res 50:1-29

Cebrian E, Ballesteros E (2009) Temporal and spatial variability in shallow- and deep-water population of the invasive Caulerpa racemosa var. cylindracea in the Western Mediterranean. Estuar Coast Shelf Sci 83:469-474
Cebrian E, Ballesteros E (2010) Invasion of Mediterranean benthic assemblages by red alga Lophocladia lallemandii (Montagne) F. Schmitz: depth-related temporal variability in biomass and phenology. Aquat Bot 92: 81-85

Coll M, Piroddi C, Steenbeek J, Kaschner K and others (2010) The biodiversity of the Mediterranean Sea: estimates, patterns, and threats. PLoS ONE 5:e11842

Coma R, Ribes M, Zabala M, Gili JM (1995a) Reproduction and cycle of gonadal development in the Mediterranean gorgonian Paramuricea clavata. Mar Ecol Prog Ser 117: 173-183

> Coma R, Zabala M, Gili JM (1995b) Sexual reproductive effort in the Mediterranean gorgonian Paramuricea clavata. Mar Ecol Prog Ser 117:185-192

Coma R, Pola E, Ribes M, Zabala M (2004) Long-term assessment of temperate octocoral mortality patterns, protected vs. unprotected areas. Ecol Appl 14: 1466-1478

> Coma R, Linares C, Ribes M, Diaz D, Garrabou J, Ballesteros E (2006) Consequences of a mass mortality event in populations of Eunicella singularis (Cnidaria: Octocorallia) in Menorca (NW Mediterranean). Mar Ecol Prog Ser 327: 51-60

> Coma R, Ribes M, Serrano E, Jiménez E, Salat J, Pascual J (2009) Global warming-enhanced stratification and mass mortality events in the Mediterranean. Proc Natl Acad Sci USA 106:6176-6181

Coma R, Serrano E, Linares C, Ribes M, Díaz D, Ballesteros E (2011) Sea urchins predation facilitates invasion in a marine reserve. PLoS ONE 6:e22017

Costello MJ, Coll M, Danovaro R, Halpin P and others (2010) A census of marine biodiversity knowledge, resources, and future challenges. PLoS ONE 5:e12110

Edmunds PJ, Carpenter RC (2001) Recovery of Diadema antillarum reduces macroalgal cover and increases abundance of juvenile corals on a Caribbean reef. Proc Natl Acad Sci USA 98:5067-5071

Gaines S, Roughgarden J (1985) Larval settlement rate: a leading determinant of structure in an ecological community of the marine intertidal zone. Proc Natl Acad Sci USA 82:3707-3711

> Garrabou J, Harmelin JG (2002) A 20-year study on life history traits of a harvested long-lived temperate coral in the NW Mediterranean: insights into conservation and management needs. J Anim Ecol 71:966-978

Garrabou J, Coma R, Benssoussan N, Chevaldonné P and others (2009) Mass mortality in NW Mediterranean rocky benthic communities: effects of the 2003 heat wave. Glob Change Biol 15:1090-1103

Gili JM, Coma R (1998) Benthic suspension feeders: their paramount role in littoral marine food webs. Trends Ecol Evol 13:316-321

Gorgula SK, Connell SD (2004) Expansive covers of turfforming algae on human-dominated coast: the relative effects of increasing nutrient and sediment loads. Mar Biol 145:613-619

> Gori A, Rossi S, Linares C, Berganzo E, Orejas C, Dale M, Gili JM (2011) Size and spatial structure in deep versus shallow populations of the Mediterranean gorgonian Eunicella singularis (Cap de Creus, Northwestern Mediterranean Sea). Mar Biol 158:1721-1732

> Gorman D, Connell SD (2009) Recovering subtidal forest in human-dominated landscapes. J Appl Ecol 46: 1258-1265 
Gosselin LA, Qian PY (1997) Juvenile mortality in benthic marine invertebrates. Mar Ecol Prog Ser 146:265-282

Gotelli NJ (1988) Determinants of recruitment, juvenile growth and spatial distribution of a shallow-water gorgonian. Ecology 69:157-166

Halpern BS, Walbridge S, Selkoe KA, Kappel CV and others (2008) A global map of human impact on marine ecosystems. Science 319:948-952

Hay ME (1981) The functional morphology of turf- forming seaweeds: persistence in stressful marine habitats. Ecology 62:739-750

Hughes TP, Baird AH, Dinsdale EA, Moltschaniwskyj NA, Pratchett MS, Tanner JE, Willis BL (2000) Supply-side ecology works both ways: the link between benthic adults, fecundity, and larval recruits. Ecology 81: 2241-2249

Hughes TP, Baird AH, Bellwood DR, Card M and others (2003) Climate change, human impacts, and the resilience of coral reefs. Science 301:929-933

> Jackson JBC, Kirby MX, Berger WH, Bjorndal KA and others (2001) Historical overfishing and the recent collapse of coastal ecosystems. Science 293:629-637

$>$ Kennelly SJ (1987) Inhibition of kelp recruitment by turfing algae and consequences for an Australian kelp community. J Exp Mar Biol Ecol 112:49-60

Klein JC, Verlaque M (2011) Experimental removal of the invasive Caulerpa racemosa triggers partial assemblage recovery. J Mar Biol Assoc UK 91:117-125

Krause-Jensen D, Sagert S, Schubert H, Bostrom C (2008) Empirical relationships linking distribution and abundance of marine vegetation to eutrophication. Ecol Indic 8:515-529

> Kuffner IB, Walters LJ, Becerro MA, Paul VJ, RitsonWilliams R, Beach KS (2006) Inhibition of coral recruitment by macroalgae and cyanobacteria. Mar Ecol Prog Ser 323:107-117

Ledoux JB, Mokhtar-Jamaï K, Roby C, Féral JP, Garrabou J, Aurelle D (2010) Genetic survey of shallow populations of the Mediterranean red coral [Corallium rubrum (Linnaeus, 1758)]: new insights into evolutionary processes and implications for conservation. Mol Ecol 19:675-690

Linares C, Doak DF (2010) Forecasting the combined effects of disparate disturbances on the persistence of long-lived gorgonians: the case study of Paramuricea clavata. Mar Ecol Prog Ser 402:59-68

Linares C, Doak D, Coma R, Diaz D, Zabala M (2007) Life history and viability of a long-lived marine invertebrate: the octocoral Paramuricea clavata. Ecology 88:918-928

Linares C, Coma R, Garrabou J, Díaz D, Zabala M (2008a) Size distribution, density and disturbance in two Mediterranean gorgonians: Paramuricea clavata and Eunicella singularis. J Appl Ecol 45:688-699

Linares C, Coma R, Mariani S, Díaz D, Hereu B, Zabala M (2008b) Early life history of the Mediterranean gorgonian Paramuricea clavata: implications for population dynamics. Invertebr Biol 127:1-11

> Mokhtar-Jamaï K, Pascual M, Ledoux JB, Coma R, Féral JP, Garrabou J, Aurelle D (2011) From global to local genetic structuring in the red gorgonian Paramuricea clavata: the interplay between oceanographic conditions and limited larval dispersal. Mol Ecol 20:3291-3305

> Nugues MM, Smith GW, Van Hooindonk RJ, Seabra MI, Bak RPM (2004) Algal contact as a trigger for coral disease. Ecol Lett 7:919-923

> Piazzi L, Ceccherelli G, Cinelli F (2001) Threat to macroalgal diversity: effects of the introduced green alga Caulerpa racemosa in the Mediterranean. Mar Ecol Prog Ser 210: 149-159

Ribes M, Coma R, Rossi S, Micheli M (2007) Cycle of gonadal development of Eunicella singularis (Cnidaria: Octocorallia): trends in sexual reproduction in gorgonians. Invertebr Biol 126:307-317

Rodriguez-Prieto C Joher S, Cebrian E (2010) Light and temperature requirements for survival and growth of Mediterranean Womersleyella setacea. Proc of the 4th Medit Symp Mar Vegetation, Tunisia, p 111-115

> Sales M, Ballesteros E (2009) Shallow Cystoseira (Fucales: Ochrophyta) assemblages thriving in sheltered areas from Menorca (NW Mediterranean): relationships with environmental factors and anthropogenic pressures. Estuar Coast Shelf Sci 84:476-482

Sales M, Cebrian E, Tomas F, Ballesteros E (2011) Pollution impacts and recovery potential in three species of the genus Cystoseira (Fucales, Heterokontophyta). Estuar Coast Shelf Sci 92:347-357

Steneck RS, Dethier MN (1994) A functional group approach to the structure of algal-dominated communities. Oikos 69:476-498

Streftaris N, Zenetos A (2006) Alien marine species in the Mediterranean: the 100 'Worst Invasives' and their impact. Medit Mar Sci 7:87-118

Vermeij MJA (2006) Early life-history dynamics of Caribbean coral species on artificial substratum: the importance of competition, growth and variations in life history strategy. Coral Reefs 25:59-71

- Vermeij MJA, Sandin SA (2008) Density-dependent settlement and mortality structure the earliest life phases of a coral population. Ecology 89:1994-2004

Vermeij MJA, van Moorselaar I, Engelhard S, Hönlein C and others (2010) The effects of nutrient enrichment and herbivore abundance on the ability of turf algae to overgrow coral in the Caribbean. PLoS ONE 5:e14312

Vighi M (1970) Richerche sul ciclo reproduttivo del corallo rosso Corallium rubrum (L.) del promotorio di Portofino. Atti Acc Naz Lincei Mem 3:1-26

Zenetos A, Gofas S, Verlaque M, Inar ME and others (2010) Alien species in the Mediterranean Sea by 2010. A contribution to the application of European Union's Marine Strategy Framework Directive (MSFD). I. Spatial distribution. Medit Mar Sci 11:381-493

Submitted: June 10, 2011; Accepted: January 5, 2012

Proofs received from author(s): April 5, 2012
Editorial responsibility: Matthias Seaman, Oldendorf/Luhe, Germany 